10. Прикладная статистика: исследование зависимостей : справ. изд. / под ред. С. А. Айвазян. - М. : Финансы и статистика, 1985.- 487 с.

11. Романенко В. Д. Методика экологической оценки качества поверхностных вод по соответствующим категориям / В. Д. Романенко [и др.]. - Киев : СИМВОЛ-Т, 1998. - 28 с.

Бедункова Ольга. Морфометрический гомеостаз ихтиоценоза и экологический статус малой реки Ровенской области. Анализ флуктуирующей асимметрии представителей ихтиоценоза малой реки Устья показал, что у рыб, отловленных в створах с минимальной антропогенной нагрузкой, стабильность развития была выше, чем у особей в пределах уробекосистемы. Самый высокий морфометрический гомеостаз имел карась, самый низкий - плотва и верховодка. Тесными оказались зависимости от уровня загрязнения поверхностных вод и дисперсией асимметрии количества жаберных тычинок в первой жаберной дуге $\left(\mathrm{R}^{2}=0,735\right)$, a также морфометрический гомеостаз плотвы $\left(\mathrm{R}^{2}=0,808\right)$ и верховодки $\left(\mathrm{R}^{2}=0,673\right)$. Стабильность развития ихтиоценоза и качество водной среды оценены как «средний уровень отклонений от нормы», III бала. Гидрохимические показатели свидетельствовали о переходе от II к III классу качества поверхностных вод. При этом в отдельных створах результаты оценок экологического статуса реки по использованным методикам не совпадали, что свидетельствует о необходимости разработок унифицированных критериев оценки состояния гидроэкосистем.

Ключевые слова: ихтиоценоз, флуктуирующая асимметрия, качество поверхностных вод.

Biedunkova Olga. Morphometric Ichthyocenosis Homeostasis and Ecological Status of The Small River of Rivne Region. Fluctuating asymmetry in fish that are caught in the sections of the river with minimal anthropogenic load showed that the stability of their development has been higher than that of individuals within urobekosistem. Highest morphometric homeostasis had the roach and the perched. It turned out to be closely based on the level of contamination of surface water and the dispersion of the asymmetry in the number of gill rakers of the first gill arch $\left(\mathrm{R}^{2}=0,735\right)$, and the morphometric homeostasis roach $\left(\mathrm{R}^{2}=0,808\right)$ and the perched $\left(\mathrm{R}^{2}=0,673\right)$. Stability and development ichthyocenosis water quality rated as «average deviation from the norm», III ball. Hydrochemical indicators showed the transition from II to III class quality of surface waters. At the same time, in separate alignments results of the evaluations of the ecological status of the river on the methodology used did not match. This demonstrates the need for development of standardized criteria for assessment of hydroecosistem.

Key words: ichthyocenosis, fluctuating asymmetry, surface water quality.

Стаття надійшла до редколегії 14.09.2015 p.

УДК 594.38:574.2

Алла Гарлінська

\title{
Будова статевої системи молюсків підродини Physinae
}

Здійснено аналіз кількісних показників статевої системи семи видів молюсків підродини Рhysinae (Physa fontinalis, Ph. adversa, Ph. skinneri, Ph. bulla, Physella acuta, Phys. heterostropha, Costatella integra) із застосуванням сучасних методів багатовимірної статистики. 3'ясовано, що кількісні ознаки статевої системи можуть бути використані для ідентифікації видів.

Ключові слова: Physinae, статева система, багатовимірна статистика, копулятивний апарат.

Постановка наукової проблеми та ії значення. Пухирчикові - це відносно невеличка родина прісноводних черевоногих легеневих молюсків (80 видів), які мають не дексіотропну, а лейотропну черепашку. Підродина Рhysinae відома з юри й розповсюджена здебільшого в Північній Америці та на півночі Євразії.

Щодо кількості видів пухирчикових у світовій фауні, а також розповсюджених у прісних водоймах Європи, достеменних відомостей на сьогодні поки що немає. Це зумовлено розбіжністю поглядів, по-перше, на систематику цієї родини й, по-друге, на таксономічний статус чималої кількості їі представників. А причина цього полягає в тому, що дослідники «східної» малакологічної школи (Я. І. Старобогатов і його послідовники) та сучасні нам західноєвропейські малакологи відзна-

(C) Гарлінська А., 2015 
чаються різними методичними підходами при визначенні критеріїв видової належності кожного 3 таксонів [2].

Аналіз досліджень цісї проблеми. Для вирішеня питань систематики черевоногих молюсків (у тому числі й молюсків підродини Physinae) часто мають значення особливості будови їхньої статевої системи. Але, ознайомившись із літературними відомостями останніх років $[5,9 ; 10-11,13]$, стало зрозуміло, що під час написання видових нарисів і складання таблиць для визначення пухирчикових автори наукових публікацій враховували конхіологічні ознаки, анатомічні же використовували не повністю. Тому актуальне проведення порівняльного аналізу видів підродини Physinae 3 урахуванням особливостей будови їхньої статевої системи [3].

Формулювання мети й завдання статті. Мета дослідження - 3'ясування таксономічного складу підродини Physinae на основі дослідження особливостей будови їхньої статевої системи із застосуванням методів багатовимірної статистики.

Завдання статті - проаналізувати мінливість кількісних ознак деяких органів статевої системи молюсків підродини Physinae.

Виклад основного матеріалу й обгрунтуваня отриманих результатів дослідження. Розглянуто кількісні характеристики таких дев'яти лінійних показників статевої системи пухирчикових, як ДКА - довжина копулятивного апарату; ДП - довжина простати; ДС - довжина сім'яприймача; ДЯ довжина яйцепроводу; ДСМ - довжина сім'яного міхура; ДМП - довжина мішка пеніса; ШМП ширина мішка пеніса; ДПр - довжина препуціума; ШПр - ширина препуціума (рис. 1).
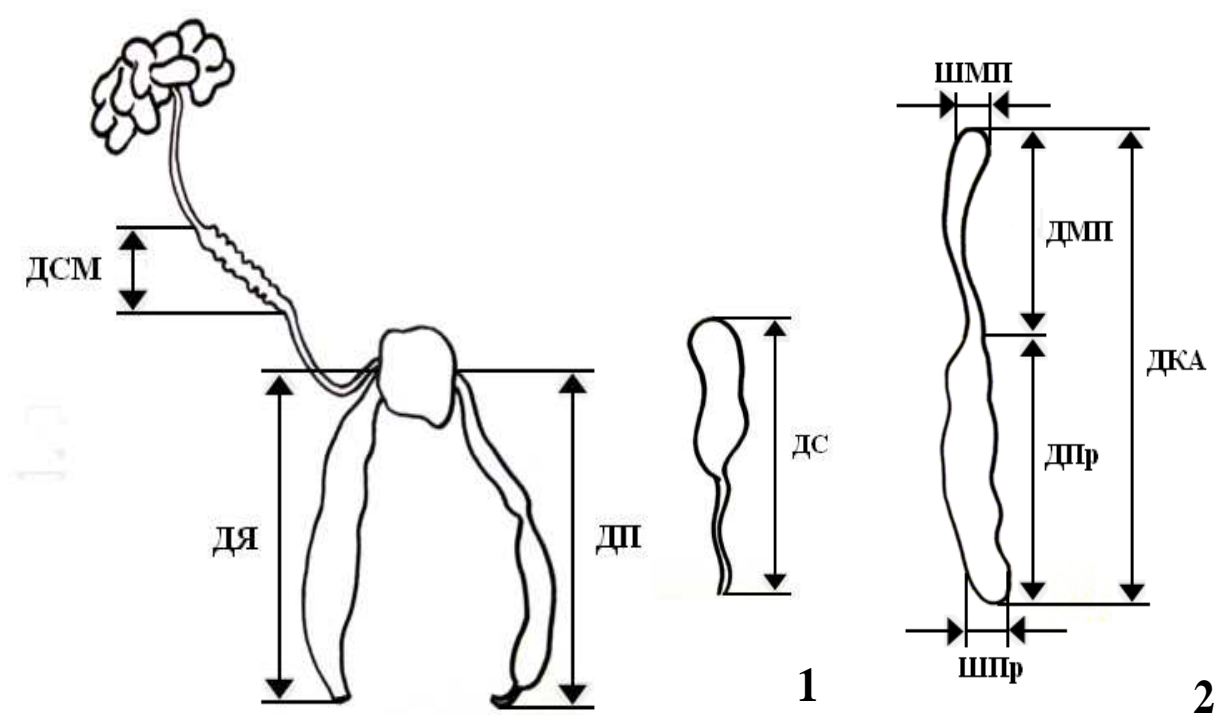

Рис. 1. Схема вимірів статевої системи й копулятивного апарату Physinae:

1) ДСМ - довжина сім'яного міхура, ДП - довжина простати, ДЯ - довжина яйцеводу,

ДС - довжина сім'яприймача; 2) ДКА - довжина копулятивного апарату, ДМП - довжина мішка пеніса, ШМП - його ширина, ДПр - довжина препуціума, Шпр - його ширина.

На підставі отриманих даних визначено шість індексів: довжину копулятивного апарату / довжину мішка пеніса (ДКА/ДМП); довжину мішка пеніса / довжину препуціума (ДМП/ДПр); ширину мішка пеніса / ширину препуціума (ШМП/ШПр); довжину копулятивного апарату / довжину препуціума (ДКА/ДПр); ширину мішка пеніса / довжину мішка пеніса (ШМП/ДМП); ширину препуціума / довжину препуціума (ШПр/ДПр). Пухирчикові - гермафродити. Для систематики Physinae як надійні діагностичні ознаки використовують деякі деталі будови їхньої статевої системи, насамперед чоловічої. Зазвичай при цьому увагу звертають на будову їхнього копулятивного апарату $[1,6,8,9,11,12,14-16]$. 


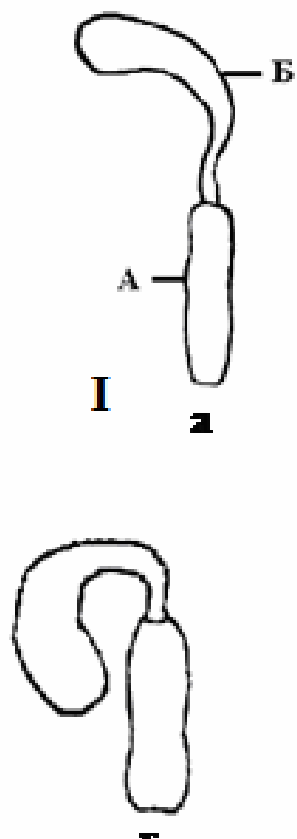

$\mathbf{T}$

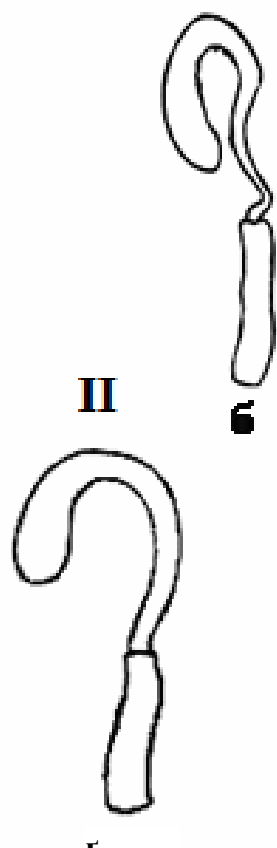

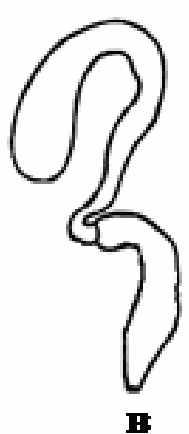

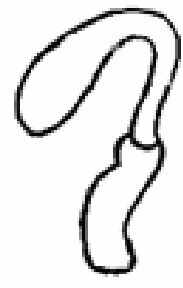

Д

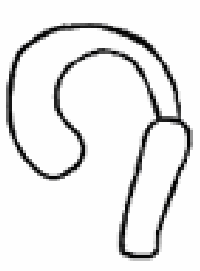

$\mathbf{e}$

Рис. 2. Схема копулятивного апарату Physinae:

Ia Ph. fontinalis (р. Серет, Тернопіль): А - препуціум; Б - мішок копулятивного органа.

II б - Ph. adversa (р. Крюків, Смичин Чернігівської обл.); в - Ph. skinneri (р. Латориця,

Соломоново Закарпатської обл.); г - Ph. bulla (р. Остер, Остер Чернігівської обл.); г - Phys. Acuta (р. Мертвовід, Вознесенськ Миколаївської обл.); д - Phys. heterostropha (р. Інгул,

Софіївка Миколаївської обл.); е - Phys. integra (р. Самара, Дмитрівка Дніпропетровської обл.).

Копулятивний апарат пухирчикових (рис. 2) представлено копулятивним органом (пеніс), який міститься в мішку копулятивного органа й передпеніального рукава (препуціум). Останній закінчується чоловічим статевим отвором. Особливість будови пеніса цих тварин - те, що інколи він має фіксаторне потовщення. Уздовж препуціума на його внутрішній стінці проходить одна м'язова складка - велюм. У стінці передпеніального рукава міститься залозисте потовщення - препуціальна залоза.

Середні значення та їх похибки, використані для аналізу параметрів статевої системи, наведено в табл. 1.

Таблиия 1

Основні лінійні параметри статевої системи молюсків підродини Physinae

\begin{tabular}{|c|c|c|c|c|c|c|c|}
\hline$\stackrel{5}{8}$ & 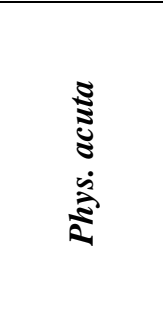 & 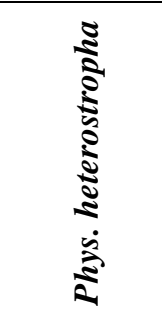 & 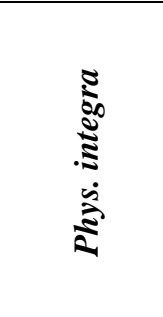 & 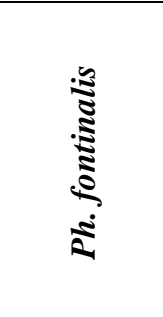 & 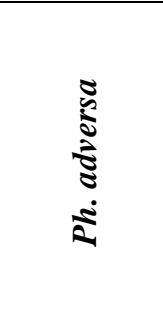 & 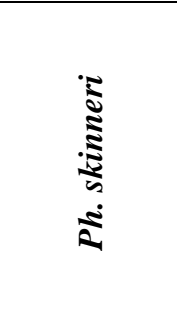 & 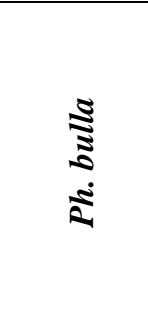 \\
\hline ДКА & $4,94 \pm 0,32$ & $4,89 \pm 0,31$ & $5,00 \pm 0,09$ & $5,17 \pm 0,23$ & $5,06 \pm 0,10$ & $10,15 \pm 0,15$ & $5,09 \pm 0,23$ \\
\hline ДП & $1,52 \pm 0,09$ & $1,53 \pm 0,09$ & $1,68 \pm 0,08$ & $1,83 \pm 0,09$ & $1,92 \pm 0,09$ & $2,54 \pm 0,06$ & $1,77 \pm 0,09$ \\
\hline ДС & $1,90 \pm 0,12$ & $1,88 \pm 0,11$ & $2,10 \pm 0,11$ & $2,41 \pm 0,07$ & $2,44 \pm 0,07$ & $3,10 \pm 0,07$ & $2,35 \pm 0,08$ \\
\hline ДЯ & $4,87 \pm 0,47$ & $9,23 \pm 5,11$ & $5,31 \pm 0,39$ & $3,06 \pm 0,18$ & $3,13 \pm 0,17$ & $3,64 \pm 0,04$ & $3,06 \pm 0,20$ \\
\hline ДСМ & $1,86 \pm 0,13$ & $1,83 \pm 0,12$ & $2,00 \pm 0,13$ & $2,45 \pm 0,09$ & $2,52 \pm 0,10$ & $3,23 \pm 0,05$ & $2,40 \pm 0,08$ \\
\hline ДМП & $2,55 \pm 0,16$ & $2,53 \pm 0,16$ & $2,61 \pm 0,04$ & $2,52 \pm 0,13$ & $2,42 \pm 0,04$ & $6,87 \pm 0,08$ & $2,47 \pm 0,13$ \\
\hline ШМП & $0,97 \pm 0,06$ & $0,94 \pm 0,05$ & $0,88 \pm 0,04$ & $1,09 \pm 0,07$ & $1,09 \pm 0,05$ & $0,98 \pm 0,04$ & $1,00 \pm 0,06$ \\
\hline ДПр & $2,39 \pm 0,16$ & $2,36 \pm 0,15$ & $2,40 \pm 0,05$ & $2,65 \pm 0,11$ & $2,62 \pm 0,05$ & $3,28 \pm 0,07$ & $2,62 \pm 0,11$ \\
\hline ШПр & $1,61 \pm 0,08$ & $1,52 \pm 0,08$ & $1,56 \pm 0,03$ & $1,46 \pm 0,05$ & $1,39 \pm 0,05$ & $1,12 \pm 0,03$ & $1,39 \pm 0,05$ \\
\hline
\end{tabular}


Згідно з результатами дискримінантного аналізу (табл. 2), лише деякі види дискримінуються на високому рівні, однак загальний рівень дискримінації низький - 65,71\%.

Таблиия 2

Матриця класифікації за лінійними параметрами статевої системи пухирчикових

\begin{tabular}{|c|c|c|c|c|c|c|c|c|}
\hline Вид & $\%$ & 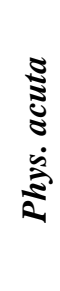 & 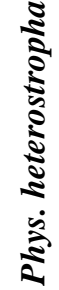 & 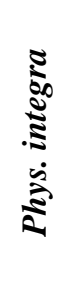 & 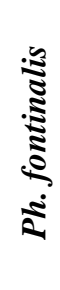 & 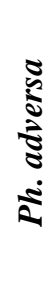 & 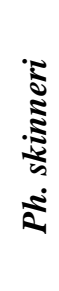 & 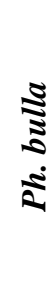 \\
\hline Phys. acuta & 80,00 & 8 & 1 & 1 & 0 & 0 & 0 & 0 \\
\hline Phys. heterostropha & 50,00 & 3 & 5 & 2 & 0 & 0 & 0 & 0 \\
\hline Phys. integra & 90,00 & 1 & 0 & 9 & 0 & 0 & 0 & 0 \\
\hline Ph. fontinalis & 50,00 & 0 & 0 & 0 & 5 & 2 & 0 & 3 \\
\hline Ph. adversa & 60,00 & 0 & 0 & 0 & 4 & 6 & 0 & 0 \\
\hline Ph. skinneri & 100,00 & 0 & 0 & 0 & 0 & 0 & 10 & 0 \\
\hline Ph. bulla & 30,00 & 0 & 0 & 0 & 4 & 3 & 0 & 3 \\
\hline У цілому & 65,71 & 12 & 6 & 12 & 13 & 11 & 10 & 6 \\
\hline
\end{tabular}

Однак, як видно з малюнка (рис. 3), чітко диференціюються три групи. Першу з них утворюють Ph. fontinalis, Ph. adversa, Ph. bulla, другу - Phys. acuta, Phys. heterostropha, Phys. integra, а третю один вид - Ph. skinneri.

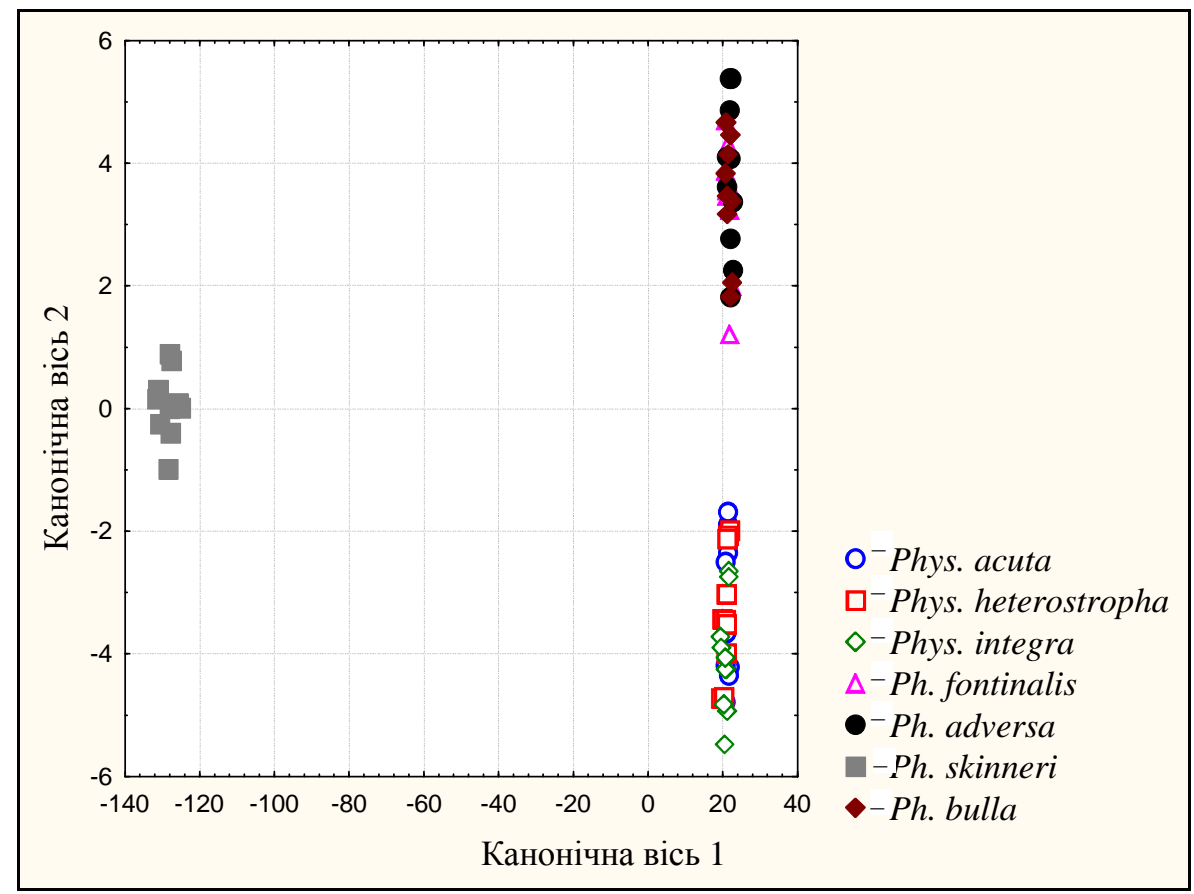

Рис. 3. Розподіл екземплярів пухирчикових за кількісними характеристиками статевої системи в площиині периих двох канонічних вісей

Висновки й перспективи подальшого дослідження. Результати аналізів кількісних характеристик статевої системи всіх семи видів пухирчикових (Ph.fontinalis, Ph. adversa, Ph. skinneri, Ph. bulla, Phys. acuta, Phys. heterostropha, C. integra), проведених із застосуванням методів багатовимірної статистики, свідчать про те, що між ними є відмінності. Так, Ph. skinneri відмежовується за першою 
канонічною віссю, яка найкраще корелює із ДКА, ДМП та їх співвідношенням. Тоді як Ph. fontinalis та $P$. acuta розмежовуються за другою канонічною віссю, що найбільше корелює 3 параметрами сперматеки і яйцепроводу.

\section{Джерела та література}

1. Акрамовский Н. Н. Моллюски (Mollusca) / Н. Н. Акрамовский // Фауна Армянской ССР. - Ереван : Изд-во АН АрмССР, 1976. - 268 с.

2. Богачова А. М. Сучасний стан і ретроспективний огляд фауни пухирчикових (Mollusca: Gastropoda: Physidae) Волинського Полісся / А. М. Богачова, А. П. Стадниченко, Л. М. Янович // Наук. конф. «Екологічний стан і біорізноманіття екосистем Шацького національного природного парку (1114 верес. 2008 р.). - Львів : СПОЛОМ, 2008. - С. 13-16.

3. Гарлінська (Лейченко) А. М. Будова тертки молюсків підродини Physinae (Mollusca: Gastropoda: Pulmonata) / А. М. Гарлінська (Лейченко) // Наукові записки Тернопільського національного педагогічного університету імені Володимира Гнатюка. - Серія : Біологія. - Спец. вип.: Молюски: результати, проблеми і перспективи досліджень. - 2012. - № 2 (51). - С. 57-62.

4. Жадин В. И. Моллюски пресных и солоноватых вод СССР / В. И. Жадин // Определители по фауне СССР, издаваемые Зоологическим институтом АН СССР. - М. ; Л. : АН СССР, 1952. - Т. $46 .-376$ с.

5. Определитель пресноводных бепозвоночных России и сопредельных территорий / [Я. И. Старобогатов, Л. А. Прозорова, В. В. Богатов, Е. М. Саенко]. - СПб. : Наука, 2004. - Т. 6. - С. 9-492.

6. Стадниченко А. П. Прудовиковообразные (пузырчиковые, витушковые, катушковые) / А. П. Стадниченко. - Киев : Наук. думка, 1990. - 290 с. - (Фауна Украины. - Т. 29 : Моллюски. - Вып. 4).

7. Старобогатов Я. И. Класс двустворчатые молюски Bivalvia. Класс брюхоногие моллюски Gastropoda / Я. И. Старобогатов // Определитель пресноводных беспозвоночных Европейской части СССР. - Л. : Гидрометеоиздат, 1977. - С. 123-174.

8. Старобогатов Я. И. Видовой состав семейства Physidae (Gastropoda: Pulmonata: Lymnaeiformes) Сибири и Дальнего Востока СССР (с замечаниями по европейским физидам) / Я. И. Старобогатов, Л. А. Прозорова, М. Н. Затравкин // Бюллетень Московского общества испытателей природы, отдел биологический, - 1989. - № 94 (1). - С 62-78.

9. Duncan C. J. The anatomy and physiology of the reproductive system of the freshwater snail Ph. fontinalis (L.) / C. J. Duncan // Proc. Zool. soc. London. - 1958. - Vol. 131. - № 1-2. - P. 55-84.

10. Glöer P. Süsswassermollusken / P. Glöer, C. Meier-Brook. - Hamburg : DJN, 1998. - 136 s.

11. Glöer P. Sübwassergastropoden. Mollusca. - Vol I : Nord- und Mitteleuropas / P. Glöer. - Hackenheim : ConchBooks, 2002. - 327 s.

12. Piechocki A. Mięczaki (Mollusca) / A. Piechocki. - Poznań : Polsca Acad. Nauk, 1979. - 187 s.

13. Piechocki A. Mięczaki / A. Piechocki, A. Dyduch-Falniowska. - Warszawa : Wyd. Naukowa PWN, 1993. $204 \mathrm{~s}$.

14. Taylor D. W. A new Pleistocene fauna and new species of fossil snails from the high plains / D. W. Taylor // Occasional Papers of the Museum of Zoology, University of Michigan. - 1954. - 557. - P. 1-16.

15. Taylor D. W. New species of Physa (Gastropoda: Hygrophila) from the Western United States / D. W. Taylor // Malacological Review. - 1988. - 21. - P. 43-79.

16. Taylor D. W. Introduction to Physidae (Gastropoda: Hygrophila) / D. W. Taylor // Biogeography, classification, morphology. Rivista de Biologia Tropical. - 2003. - 51. - Suppl. 1. - P. 1-287.

Гарлинская Алла. Строение половой системы моллюсков подсемейства Physinae. Анализ морфологических параметров видов подсемейства Physinae, как и анализ алозимной изменчивости, доказывают, что в фауне Украины это подсемейство представлено тремя видами - Physa fontinalis, Ph. skinneri, Phys. acuta. При этом надежная их идентификация на основе лишь конхиологических признаков является достаточно проблематичной. Надежнее будет использование некоторых анатомических признаков. Так, Physa skinneri хорошо дифференцируется от других за длиной копулятивного аппарата, длиной мешка пениса и их соотношением, а Physa fontinalis и Physella acuta - достоверно по параметрам сперматеки и яйцевода.

Ключевые слова: Physinae, половая система, многомерная статистика, копулятивный аппарат.

Garlinska Alla. The Structure of Physinae Subfamily Mollusc Reproductive System. The analysis of morphometric parameters of Physinae subfamily species and the analysis of allozymic variability as well prove this subfamily to be represented with three species - Physa fontinalis, Ph. skinneri, Physella acuta in the fauna of Ukraine. But their reliable identification based only on conchiological signs is rather a problem. The use of some anatomical signs is more reliable. Thus, Ph. skinneri is well differentiated from others with the length of copulative apparatus, the 
length of the penis bag and their correlation; Ph. fontinalis and Phys. acuta are reliably differentiated with spermatheca and oviduct parameters.

Key words: Physinae, reproductive system, multivariate statistics, copulative apparatus.

Стаття надійшла до редколегії 16.02.2015 p.

УДК 595.771

Наталія Кілочицька, Ольга Стеценко

\section{Зміни кількісного та якісного складу антропофільних видів кровосисних комарів Канівського природного заповідника}

Аналіз ентомологічних зборів Канівського природного заповідника за 2006 та 2015 рр. показав суттєві відмінності в чисельності (домінуючий у 2006 р. Aёdes vexans поступився місцем у 2015 р. Culex modestus) i видовому складі (уперше на території заповідника відзначено Culiseta alaskaensis) антропофільних видів кровосисних комарів. Ці відмінності обумовлені суттєвою різницею гідрологічного й температурного режимів у ці роки, що, зі свого боку, зумовило різну кількість і тип куліцидогенних водойм на території заповідника.

Ключові слова: кровосисні комарі; кліматичні зміни; Канівський природний заповідник.

Постановка наукової проблеми та ії̈ значення. Канівський природний заповідник - база проведення літньої навчальної практики студентів. У середньому протягом половини року в межах заповідника перебуває понад тисяча осіб. Одним із факторів потенційної небезпеки виступають кровосисні комарі - докучливі кровососи та переносники паразитарних інвазій, вірусних і бактеріальних інфекцій. Ключову роль у життєвому циклі комарів відіграють чинники природного середовища коливання зимових та літніх температур, сонячної радіації, вологості, ступеня мінералізації водойм, наявності джерела живлення - хазяїв, екстремальні відхилення яких від оптимуму негативно впливають на чисельність комарів. Такі фактори, як опади й вітер, механічно впливають на літ імаго та розвиток личинок комарів у водоймах.

Мета та завдання дослідження. Мета статті - визначення факторів, які спричиняють зміни чисельності та видового складу в популяціях кровосисних комарів Канівського природного заповідника. Завдання роботи - визначення видового складу антропофільних комарів, визначення видівдомінантів, аналіз кліматичних умов досліджуваних періодів, установлення причин змін чисельності й видового складу комарів у зборах за 2006 та 2015 pp.

Матеріали й методи дослідження. Матеріал зібраний на території Канівського природного заповідника методом «збору на собі» (відлов протягом 30 хв, обліки - двічі на добу протягом 36 діб) на контрольних ділянках [5]. Збір комарів у приміщеннях проводили за допомогою ексгаустера. Визначення самок імаго здійснено з використанням визначника А. В. Гуцевич, А. С. Мончадський, А. А. Штакельберг [1].

Індекс домінування Бергера-Паркера визначали за формулою [4]:

$$
D i=n i / N \cdot 100 \text {, }
$$

де: $n i$ - кількість особин аналізованого виду; $N$ - загальна кількість особин комарів у вибірці.

Виклад основного матеріалу й обгрунтування отриманих результатів дослідження. Для 3'ясування можливих причин змін чисельності та видового різноманіття антропофільних видів комарів у регіоні нами проведено порівняльний аналіз цих показників у 2006-му та 2015 рр. на фоні суттєвих відмінностей кліматичних умов.

Характерними особливостями кліматичних умов 2006 р. були холодна, затяжна й сніжна зима та велика кількість опадів протягом теплого періоду року (рис. 1,2). Це спричинило, насамперед, появу навесні великої кількості тимчасових і напівпостійних водойм (заповнені талою водою канави, вирви, пониження берегової смуги річок, заболоченості тощо) та, як наслідок, сплеску чисельності й

(C) Кілочищька Н., Стецеенко О., 2015 